Originalartikkel

\title{
Strålebeskyttelse av barns bryst ved høyoppløselig CT av lungene
}

\begin{abstract}
Sammendrag
Bakgrunn. Statens strålevern anbefaler vismut som beskyttelse av strålefølsomme overflateorganer ved CTundersøkelser. I studien vurderes nytten av denne typen stråleskjerming av unge jenters bryster ved høyoppløsnings-CT (high resolution computed tomography; HRCT) ved utprøving på fantom.
\end{abstract}

Materiale og metode. Skjold med ett, to og tre lag vismut ble lagt over et homogent fantom. Bildestøy, artefakter og CT-tall (gråtoner i bildet, som beskriver vevets tetthet) ble vurdert fra bildeopptakene. Stråledosen ble målt i barnefantom.

Resultater. CT-tall ble målt i flere punkter i bildene. I de to øverste centimeterne av fantomet var CT-tallene inntil $33 \%$ forhøyet med to og tre lag vismut i forhold til bildet uten vismut. Med ett lag var CT-tallene inntil $8 \%$ forhøyet. Støy i bildene ble målt på samme måte, og var opptil $56 \%$ forhøyet ved bruk av to og tre lag vismut, og opptil $14 \%$ forhøyet med ett lag. Overflatedosen i brystregionen ble redusert med $30 \%$, $45 \%$ og $75 \%$ med hhv. ett, to og tre lag vismut.

Fortolkning. Bruk av skjold med ett lag vismut ser ut til å ha liten innflytelse på CT-bildene. Barneradiologisk avdeling ved Ullevål universitetssykehus benytter nå vismutbeskyttelse med ett lag vismut ved høyoppløsnings-CT av jenter opptil 16 år.
Hilde Kjernlie Sæther

sthf@uus.no

Anne Catrine Trægde Martinsen

Kompetansesenter for diagnostisk fysikk

Sentralradiologisk avdeling

\section{Lena Korsmo}

Tor Reiseter

Anne-Cath Vestlys avdeling

Ullevål universitetssykehus 0407 Oslo

CT er undersøkelser som gir høye stråledoser til pasient, og bruk av CT har økt kraftig de siste årene (1). Barn er spesielt følsomme for ioniserende stråling. FN anslår at de har 2-3 ganger større sannsynlighet for å få senvirkninger, og da i hovedsak kreft, i løpet av livet som følge av bestråling, enn voksne (2). Det er derfor spesielt viktig under CTundersøkelser av barn, at stråledosen er så lav som mulig. Høyoppløsnings-CT av unge jenter gir en betydelig stråledose til brystene. Bryster er spesielt strålefølsomme organer, særlig når de er i vekst (3). Statens strålevern anbefaler bruk av vismut som beskyttelse av strålefølsomme overflateorganer under CTundersøkelser (4). For barn er ikke vismutskjold kommersielt tilgjengelig, og AnneCath Vestlys avdeling, Barneradiologisk avdeling ved Ullevål universitetssykehus ønsket derfor å undersøke om det var mulig å bruke denne typen strålebeskyttelse på barn, og hvor tykt det burde være ved høyoppløsnings-CT av unge jenter. For å undersøke dette ble vismutskjold av ulike tykkelser prøvd ut på fantomer.

\section{Materiale og metode}

Vismutskjold er et strålebeskyttende skjold (F \& L Medical Products, Vandergrift, PA, USA) som består av grunnstoffet vismut innbakt i lateks. Vismutskjoldet legges i selve strålefeltet under CT-undersøkelser, og vismuten i skjoldet absorberer noe av strålingen, slik at underliggende vev får en redusert stråledose (4). Materialet egner seg derfor godt som strålebeskyttende materiale for strålefølsomme overflateorganer. Hvert flak med vismut innbakt i lateks har en blyekvivalens på $0,015 \mathrm{~mm}$ bly (5). Det ble laget vismutskjold med ett, to og tre lag vismut for å undersøke hvor mange lag med vismut som var hensiktsmessig å bruke. Disse ble lagt over et $1 \mathrm{~cm}$ tykt lag med skumgummi for å løfte eventuelle artefakter vekk fra det diagnostisk interessante området.

Opptakene ble gjort med en dual slice GE
HiSpeed NX/i Pro, med standard HRCTprotokoll, med $120 \mathrm{kV}, 80 \mathrm{~mA}$, aksiale snitt på $1 \mathrm{~mm}$ med intervall $10 \mathrm{~mm}$, rotasjonstid på 0,7 sekunder, 15 bilder.

To fantomer ble skannet med ett, to og tre lag vismut. For å vurdere støy, artefakter og CT-tall (pikselverdiene i bildet, som beskriver tettheten til vevet og gir ulike gråtoner) ble det benyttet et homogent fantom av perspeks med diameter $16 \mathrm{~cm}$ (RTI Electronics $\mathrm{AB}$, Sverige). Bildene av det homogene fantomet ble vurdert ved at støy og CT-tall ble målt gjennom fantomet fra regionen rett under vismutskjoldet, og nedover i bildet av fantomet. CT-tall er pikselverdiene i CT-bildet, som gjenspeiler tettheten i tilhørende vev. Dette gir oss gråtonene i CT-bildet, og kontrasten mellom disse gjør at man kan skille ulike organer med ulik tetthet. Bildene ble også vurdert med henblikk på hvor artefaktene fra vismuten plasserte seg.

Til dosemålingene og vurdering av artefakter ble det benyttet et antropomorft fantom av en ettåring (CIRS Tissue Simulation Technology, USA, Modell 704-D). Det ble målt overflatedose i brystregionen, og dose til lungevev. Dosemålingene ble gjort med TLD (Thermo Luminescence Dosemeters) (TLD 200, Harshaw, USA). Dosimetrene er krystaller av litiumfluorid som absorberer ioniserende stråling, og kan avleses etter bruk. Dosimetrene ble tapet i par til hvert bryst på fantomet, og lagt inn i lungevevet $i$ fantomet. Disse ble byttet for hvert skann, og avlest $\mathrm{i}$ etterkant. De har normalt en feilmargin på $20 \%$ (6).

\section{Resultater}

Bildene av det homogene fantomet ble vurdert med tanke på støy, CT-tall og artefakter. Støy og CT-tall ble målt i bildene fra opptak

\section{Hovedbudskap}

- Vismut anbefales som strålebeskyttelse av strålefølsomme overflateorganer ved CT-undersøkelser, men er ikke kommersielt tilgjengelig for barn

- Vi ønsket å vurdere om vismutskjold kan brukes ved aksial høyoppløsningsCT av unge jenter

- Vismutskjold kan brukes i ett lag, og dermed vil stråledosen reduseres ved denne typen undersøkelse av unge jenter 


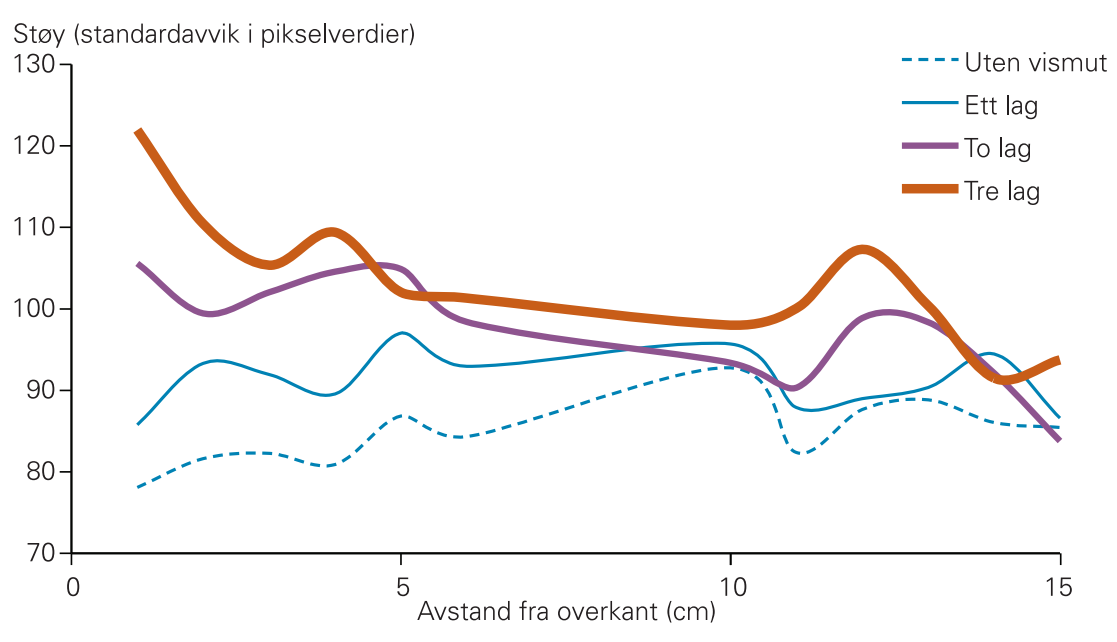

Figur 1 Støy som funksjon av måleposisjon i fantombilde for ulike vismuttykkelser

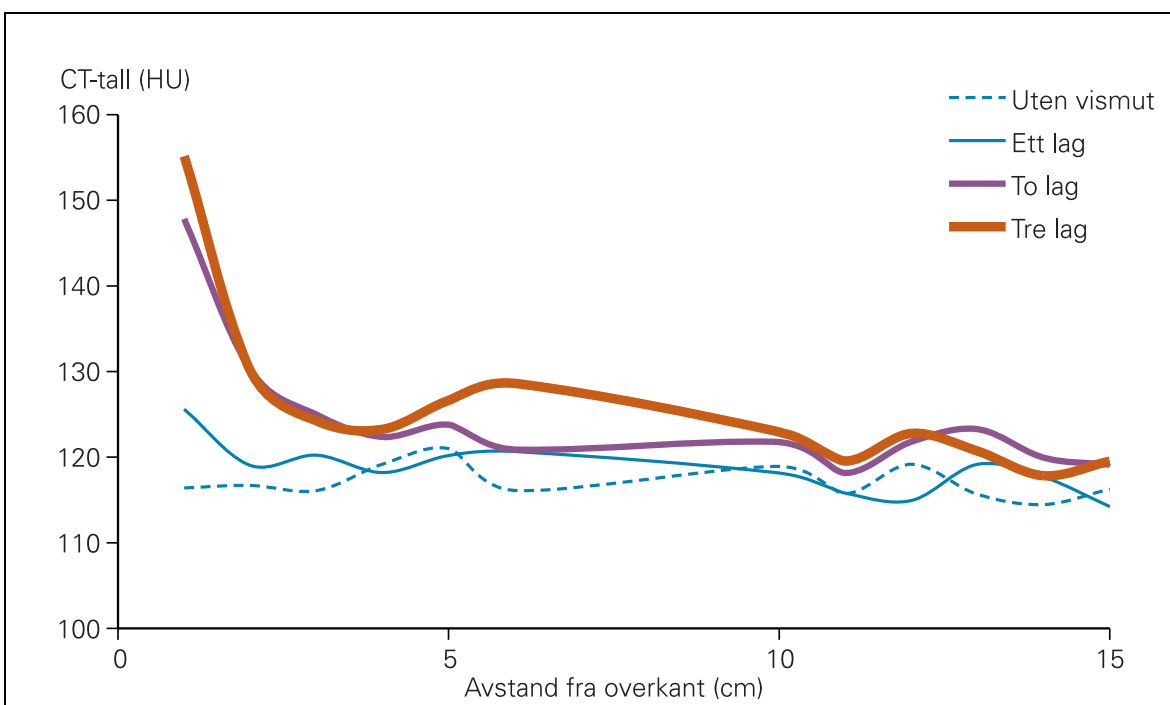

Figur 2 CT-tall som funksjon av måleposisjon i fantombilde ved ulike vismuttykkelser. $H U=$ Hounsfield -enheter

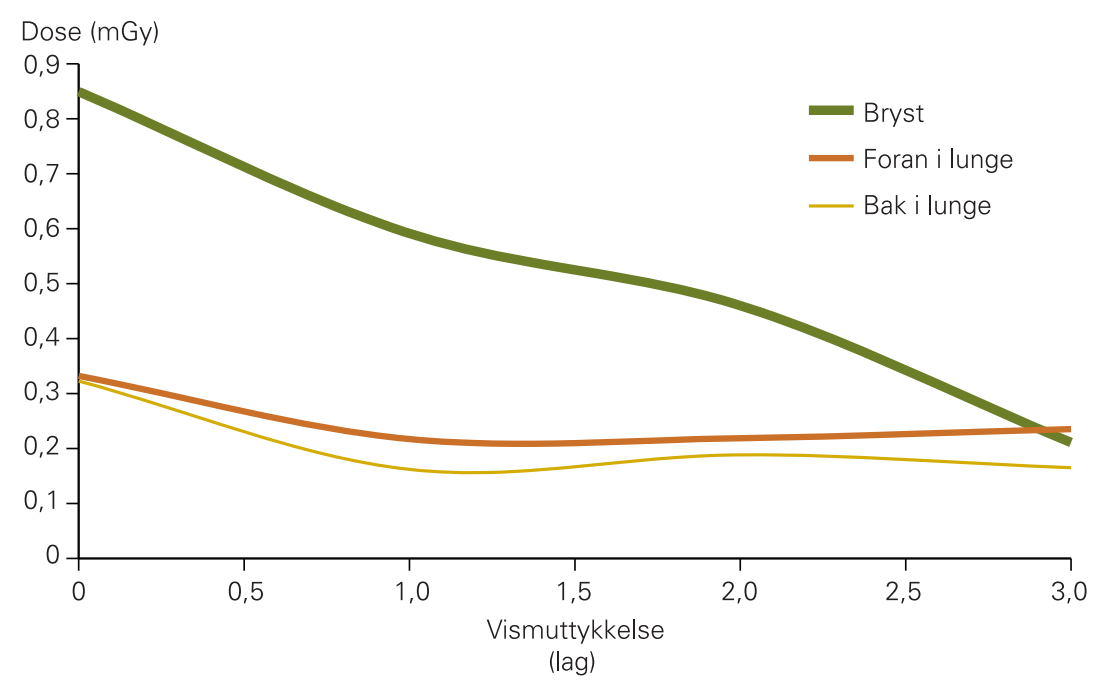

Figur 3 Dose som funksjon av vismuttykkelse i bryst og lunge med ingen, ett, to og tre lag vismut. Støy og CT-tall ble vurdert ved at gjennomsnittlig pikselverdi og standardavvik ble målt i 12 sirkulære områder med $1 \mathrm{~cm}$ mellomrom nedover $\mathrm{i}$ fantomet. Verdiene ble plottet $\mathrm{i}$ figur 1 og 2 som funksjon av avstand fra fantomets overkant for de ulike vismuttykkelsene. I de to øverste centimeterne i fantomet mot vismutskjoldet var CT-tallene inntil $33 \%$ forhøyet med to og tre lag vismut i forhold til bildet uten vismut. Med ett lag var CT-tallene inntil $8 \%$ forhøyet. Støy i det samme området var inntil $56 \%$ forhøyet med to og tre lag vismut $\mathrm{i}$ forhold til bildet uten vismut, og inntil $14 \%$ forhøyet med ett lag.

Dosene til brystene målt med dosimetrene er i figur 3 gjengitt som gjennomsnittet av dosen fra fire dosimetre for hver måling. Det var stor spredning i målingene. Dosen til brystene sank gjennomsnittlig med 30\% ved bruk av ett lag vismut. Ved bruk av to og tre lag sank dosen med hhv. $45 \%$ og $75 \%$. Dose til lungevev var meget lav både med og uten bruk av vismut. Bildene av barnefantomet ble også vurdert kvalitativt med henblikk på artefakter. Det var tydelige artefakter rundt vismutskjoldet og ut på sidene, men i bildene med ett lag vismut ble det ikke funnet artefakter som påvirket det diagnostisk aktuelle området. I bildene med to og tre lag vismut var effekten av forhøyede CT-tall synlig ved at bildene var noe lysere (høyere pikselverdier) i området rett under skjoldet.

\section{Diskusjon}

Dosemålingene viser at $\mathrm{i}$ alle tilfeller reduseres dosen til brystene betraktelig ved bruk av vismutskjold. Det var stor spredning $\mathrm{i}$ dosemålingene, trolig på grunn av stor usikkerhet i målinger gjort med TLD (Thermo Luminescence Dosemeters) generelt. Allikevel er den gjennomsnittlige dosereduksjonen i samme størrelsesorden som ved andre studier $(5,6)$, og det vil i så måte være ønskelig å kunne anvende disse i klinikken så lenge bildekvaliteten er tilfredsstillende. Bildekvalitetsmålingene viser at støy i bildene øker når dosen går ned, noe som er forventet. Økning i støy ved bruk av ett lag vismut er beskjeden, og mesteparten av denne økningen ligger i området rett under vismutskjoldet, $i$ et område som normalt ikke er diagnostisk interessant ved denne type undersøkelse. CT-tallene er også forhøyet i området rett under skjoldet, noe som kommer av en herdingseffekt (beam hardening), der strålen blir filtrert gjennom vismutskjoldet og får en høyere gjennomsnittsenergi etterpå. Strålingens dempning i vev og fantomer avhenger av strålens energi, og CT-tallene påvirkes dermed av denne filtreringen. Allikevel er det kun rett under skjoldet at denne effekten er tydelig (fig 2), slik at dette ikke vil påvirke diagnostisk kvalitet i bildene. Artefaktene i form av striper rundt skjoldet er tydelige, men ble vur- 


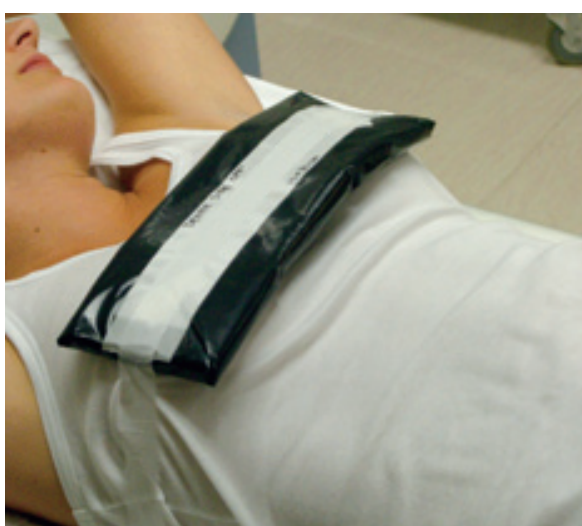

Figur 4 Illustrasjonsfoto. Plassering av vismutskjold under høyoppløsnings-CT av jente

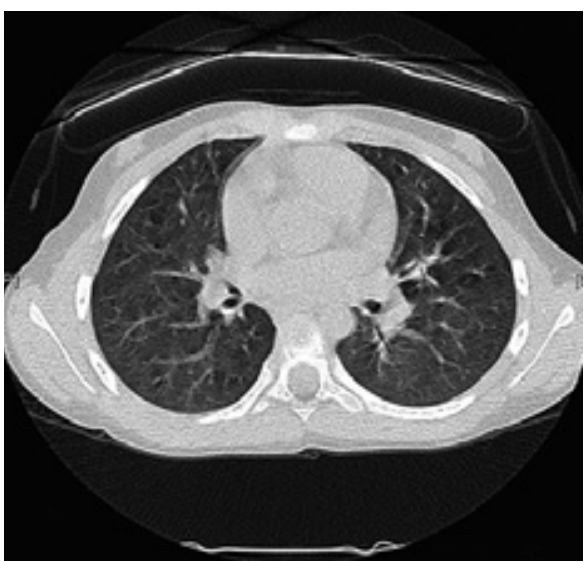

Figur 5 Høyoppløsnings-CT av jente med bruk av vismutskjold over brystene dert av radiolog til ikke å påvirke de diagnostiske områdene.

Dosereduksjonen til brystene er betydelig ved bruk av kun ett lag vismut, og ett lag vismut ga mindre artefakter, støy og herdingseffekter enn to og tre lag. På bakgrunn av dette ble bruk av skjoldet med ett lag vismut vurdert som trygt, og det ble bestemt at skjoldet skulle benyttes på pasienter (fig 4). Ved Ullevål universitetssykehus er ett lag vismut nå i rutinemessig bruk som strålebeskyttelse av brystene til jenter under 16 år som kommer til aksial høyoppløsnings-CT av lungene. Skjoldet plasseres over $1 \mathrm{~cm}$ skumgummi og er laget $\mathrm{i}$ ulike størrelser for å passe best mulig til barna som kommer inn til undersøkelse. Dette er viktig for å unngå artefakter (striper i bildene) som følge av at skjoldet henger for langt ned på sidene. Av hygieniske grunner pakkes skjoldene inn i plast, og festes deretter på pasienten med tape. Dette gjør at både plast og tape enkelt kan fjernes etter undersøkelsen, hvilket ikke er mulig hvis skjoldene festes direkte med tape uten plast mellom. CT-bildene av unge jenter med vismut over brystene ser eksempelvis ut som i figur 5. Bildene vurderes som diagnostisk tilfredsstillende av barneradio$\log$, da artefaktene rundt skjoldet verken når inn gjennom thoraxveggen eller påvirker fremstillingen av bein- og bløtvev.

Ved bruk av vismutbeskyttelse under vanlige volumopptak med kontrast vil man også kunne oppnå dosereduksjon til strålefølsomme organer ved forhåndsdefinerte opp- taksparametere. Imidlertid er det vanlig å bruke automatisk dosemodulering under disse volumopptakene, noe som vil kunne oppveie dosebesparelsen eller i verste fall øke stråledosen til pasienten ved bruk av vismutskjold. Dette er avhengig av hvilken type skanner man bruker.

\section{Oppgitte interessekonflikter: Ingen}

\section{Litteratur}

1. Børretzen I, Lysdahl KB, Olerud HM. Diagnostic radiology in Norway - trends in examination frequency and collective effective dose. Radiat Prot Dosimetry 2007; 124: 339-47.

2. UNSCEAR (United Nations Scientific Committee on the Effects of Atomic Radiation). Sources and effects of ionizing radiation. 2000 report - vol II: effects. New York: FN, 2000. www.unscear.org/ unscear/en/publications/2000_2.html (19.9.2008).

3. Annals of the ICRP. 2007 Recommendations of the International Commission on Radiological Protection. ICRP publication 103. Oxford: Pergamon 1991

4. Veileder 5 om medisinsk bruk av røntgen- og MRapparatur underlagt godkjenning. Veileder til forskrift om strålevern og bruk av stråling. Oslo: Helse- og omsorgsdepartementet, 2005.

5. Hopper KD, King SH, Lobell ME et al. The breast: in-plane $x$-ray protection during diagnostic thoracic CT - shielding with bismuth radioprotective garments. Radiology 1997; 205: 853-8.

6. Fricke BL, Donnelly LF, Frush DP et al. In plane bismuth breast shields for pediatric CT: effects on radiation dose and image quality using experimental and clinical data. AJR Am J Roentgenol 2003; 180: 407-11.

Manuskriptet ble mottatt 4.10. 2007 og godkjent 11.4. 2008. Medisinsk redaktør Åslaug Helland. 